\title{
Effects of Co 60 Gamma Irradiation on Corn Pollen
}

\author{
Vicenle Rodriguez und D. B. Linden ${ }^{1}$
}

\section{INTRODUCION}

Both sarsely and densely ionizing rarliations have been useful tools for tescurcher working in the field of biology. 'To the plant breeder, ionizing radiations have come to represemb a powerful source to increase the frequency of mutations and thus enhane the chances of obtaining some that secm to be useful.

Application of radiation to seeds and pollen grains of several plant, species has been made by many investigators. Criteria used to measure the effects of radiations have been based mainly on inhibition of pollen germination, pollen-tube growth, and pollen-tube mitosis (2). ${ }^{2} F_{1}$ and $F_{2}$ generations from treated pollen grains and seeds have also been studied. Gernination ability of sceds frum irradiaied pollen or seeds themselves, as well as seedling height and survival, have also been used to measure the affects of radiations (2).

lior the experiment to be reported bere mature corn pollen was irradiuted with 60 gamma rays, and then applied to silks of the lemale plants 24 and 48 hours after trealment. The purpose of the experiment was to delermine whether there were any differences in the number of "good" keruels per car, germination ability, and secdling height when pollen was used 24: and 48 hours after itradiation, as well as to obtain the dose resjonse of these characters. No cytological observations of the pollen tube or pollen-tube germination wore made in this cxpcriment. Corn pollen., becausc of its trinucleate condition at malurity, presents many dificultics for germination studies in vitro (1).

\section{REVILW OF JITERATURE}

Responses of pollen to treatment with ionizing radialions are different, depending upon the characteristics under study. Mericle and Mericle (7) reported that pollen germination and pollen-tube growth were greatly inhibited with doses of radiation (LD50 ranging up to $55,000 \mathrm{r}$. Tube elongation needed median lethal doses of $25,000 \mathrm{r}$, while for pollen-tube cytology stuties a median dosage of $250 \mathrm{r}$ was necessary. For endosperm and $\mathrm{F}_{1}$ mutation studies $1,000 \mathrm{r}$ were nocoled, and for mean lethal seed treatment, from $1,000 \mathrm{r}$ to $2,000 \mathrm{r}$ were used $(\gamma)$.

\footnotetext{
' Resenrch Assistnnt and Associate Scientist Ir, Puerto Rico Nuclear Center, Mayagüez, P.R.

2 Italic numbers in parentheses refer to Literature Cited, pp. 16-17.
} 
A rery detailed review of literalue on radiosensitivity of pollen from different plant speries has been made by Browbakn and Emery (2). Comparisons of $\mathrm{X}$-rays and ultroviolet light $(8,11,13)$ and $\mathrm{X}$-rays and neutrons $(3,1,5,6,12)$ have also been made, showing some diflerences anong treatments. Radiosensitivily of pollen grains is influenced and modified by well-known factors such as oxygen, storage, and freezing (2). Desiceation of pollen, slage of malurity, size of pollen gruin, and content of $\$ and 13 are also fartors that allect radiosensitivity of the pollen (2).

Data on pollen radiosensitivity are quite complete lor many plant species. Because of its lrinueloate condition al matimity, rala are far from salisfactory for com pollen, except for cylologieal studies, as stated by Brewbaker and Fmery (g). Some studies on seedling height and survival to maturity have been made by frolik and Morris (5) after irradiating corm lasscks in a nuclear reactor.

Treatments with X-rays and neutrons (fast and thermal) of barley seeds have been periormed by Caldecott (3). Subsequent seedling growilh and $F_{1}$ abnormalities from treated pollen have been made by Schunidt and Frolik (12), after irradiation in a muclear reactor. According to Brewbaker (1), resulls are not complctely reliable because gamma contanination was not laken into account

\section{MATERIALS AND METHOHS}

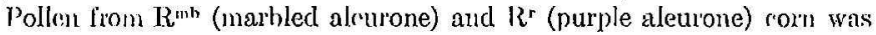
irradiated in a Co 60 gamma source with doses from 250 to $20,000 \mathrm{r}$, at: intervals of 250 up to 1,500 r, and intervals of 500 up to $20,000 \mathrm{r}$. Irradin tion of the exeised corn tassels was accomplished by putfing them in a polyethylene botte with eirculating compressed air: The bolte was lowered into the Puerto Riro Nurlear Center Co 60 ganuma pool where a 2,400-r'. source is housed.

After in'adiation, fassels were bigged individually and kept. in tapwater a6 room conditions for 24 hours. At this tine the first pollination was uade. After the pollination the used tassels were bagged again and placod in the flasks containing tapwater and kept for another 24 hours, when the second pollination was made. Ten ears were pollinated as five tassels were irradiated at each dose Ievel.

Gross pollen observations under a stereoscope revealed that a very high percentage of pollen appeared normal when used even at the nighest doses which went to $20,000 \mathrm{r}$. However, no sced was obtained in ears from tassel doses above 4,000 r. Approximately 1 month aftor pollination the ears were harvested and the number of well-developed kermels per rar was determined. These sceds were planted in flats containing about 50 -percent soil and 50-percent cachoza (a sugarcane end-product) and put in growth 
rhambers lor seoring germination perentage I week after planting. The socelling lejght wats measured 1 and 2 woeks after planting. Temperature in the growth chamber was $70^{\circ} l$. at night and $85^{\circ} \mathrm{r}$. during the day cycle. Both temperature and humidity were checked with a Brown recorder.

\section{EXPERIMENTAL, RESLLTS}

The avertige number of good kernels per ear is presented in table 1 . Result: ure quits similar for both groups, even though consistency in the

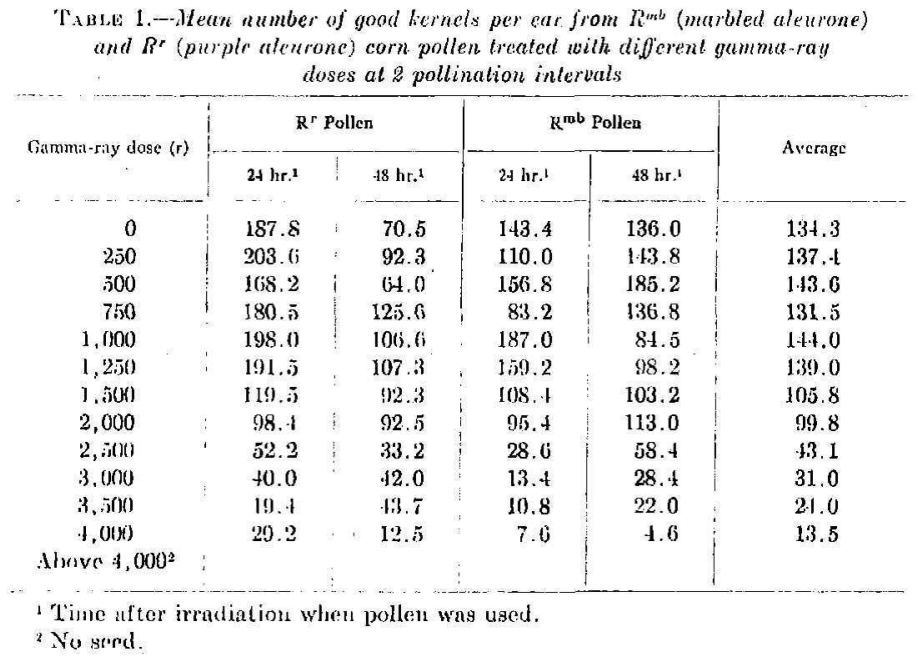

pattern followed is different, being more uniform for the group from $R^{r}$ pollet1.

When arailable, 25 seeds per ear were planted in flats and the gernination pertentage was stored at 7 days after planting. In some of the higher dosages, especially l'rom 2,500 up to $4,000 \mathrm{r}$, it was quite difficult to get suffieient sceds ?or testing germination. Table 2 shows the results of germination-ability.

As can be observed, there is not a consistent pattern between pollen used 24 hours after treatment and pollen used 48 hours after trentment. At some points the 48-hour pollen has appurently produced kernels with better germination ability. There is a dose response in both groups and 
with both ages of pollen within groups. The germination perentage docreased with increased dose.

Seedling height was measured 1 and 2 wecks after planting. 'Table i3 shows the average seedling height for each sample of reeds tested for every elipsing time and each dose.

In the range from 0 to $2,500 \mathrm{r}$ sufficient seedlings were obtained to produce a reliable mean height for cach dose treatment. No statistically signifirnut differenees were observed for seedlings coming from pollen used at 24 hours from that used at 48 hours after irmdiation.

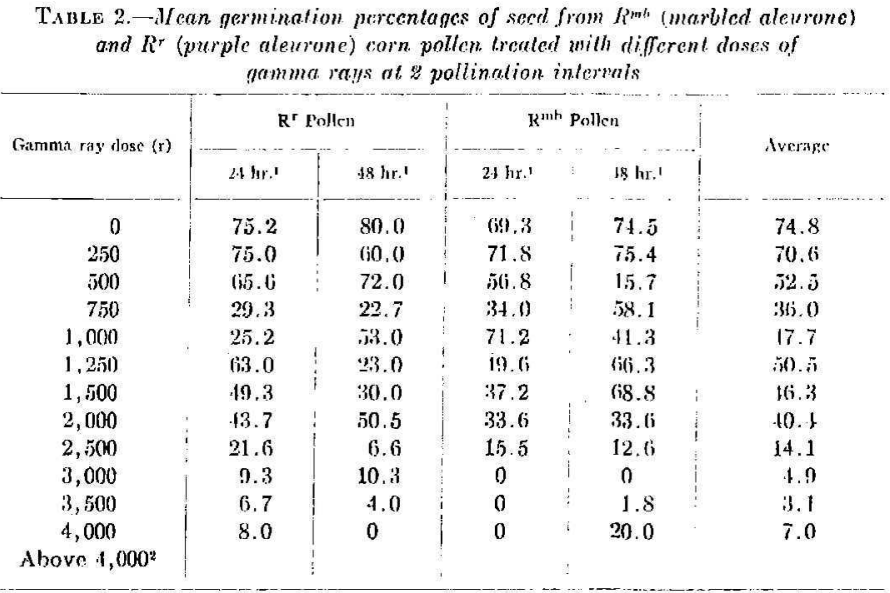

1 Time niter irradiation when pollen wis used.

2 No sced.

Figures corresponding to doses from 3,000 ? 104,000 r we not. reliable since the number of seedlings obtuined at these levels were one or two per treatment, but they are presented as they wore measured.

\section{DISCUSSION AND CONGLUSIONS}

The effects of different kinds of radiations as measured in tems of pollentube germination, pollen-tube elongation, production of viable seeds, and studies on seedling height and survival have been studied by many workers in several plant species $(3,4,5,7,8,11,12)$. In the experinu rut reported here the number of "good" kernels per ent, the germination percentage, and seedling height were studied. 
"Good" kernels (at lime of classification it was not known whether they were viable or not) could have been proctuced by genetically damaged pollen nuclei. Pollen irradiation may lead to inpruirment of viable-seed production, prinatily via its effects on: 1, Pollen germinalion; 2, zygote formation and embryo growth; 3, endospern development; 4, viability of the mature seeds; and 5, "death" of secdling (2). Since our material is corn (trinucleate pollen), both generative nuclei can be affected inde-

\begin{tabular}{|c|c|c|c|c|c|c|c|c|c|c|}
\hline \multirow{3}{*}{ 1)ose (r) } & \multicolumn{5}{|c|}{7 dias } & \multicolumn{5}{|c|}{14 dilys } \\
\hline & \multicolumn{2}{|c|}{$R^{r}$ Pollen } & \multicolumn{2}{|c|}{$\mathrm{R}^{m b}$ Pollen } & \multirow{2}{*}{ Avcragc } & \multicolumn{2}{|c|}{$R^{\mathrm{T}}$ Pollen } & \multicolumn{2}{|c|}{$\mathrm{R}^{\mathrm{ml} \text { ' Pollen }}$} & \multirow{2}{*}{ Average } \\
\hline & $24 \mathrm{hr}: \mathrm{I}$ & 18 lir.' & $2+$ lir. ${ }^{2}$ & 48 lir. & & $2.1 \mathrm{hr} \cdot \mathrm{H}$ & 18 hr. & $2+4$ th. 1 & 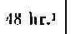 & \\
\hline 0 & 0.3 & 7.9 & 7.9 & 0.1 & $8.4 \mathrm{i}$ & 33.98 & 32.5 & 34.9 & 37.01 & 34.6 \\
\hline 250) & 7.8 & (i.1 & 8.1 & 7.2 & 7.3 & 3.8 .5 & 36.4 & 38.0 & 36.8 & 37.4 \\
\hline 500 & 5.1 & 5.6 & 5.5 & 3.3 & +.9 & 33.2 & 35.0 & 33.3 & 29.0 & 32.8 \\
\hline Tito & 4.7 & 6.8 & .5 .2 & 5. 0 & 5.6 & 28.8 & 31.3 & 34.7 & 3.1 .6 & 32.4 \\
\hline 1,000 & 5.0 & 8.9 & 9.3 & 5.0 & 7.0 & 27.7 & 37.6 & 39.4 & 29.2 & 33.5 \\
\hline 1,250 & 5.8 & 8.8 & 7.2 & 9.7 & 7.9 & 34.2 & 37.8 & 38.4 & 39.2 & 37.4 \\
\hline 1,500 & 7.8 & 7.3 & 5.3 & 5.8 & 6.0 & 30.0 & 39.6 & 27.0 & 31.7 & 33.8 \\
\hline 2,000 & 8.6 & 9.0 & 4.2 & 4.7 & 6.6 & 36.0 & 37.3 & 20.7 & 23.5 & 20.4 \\
\hline 2,500 & 7.8 & 6.8 & 4.3 & 6.0 & 0.2 & 35.9 & 32.8 & 26.2 & 25.1 & 30.0 \\
\hline 3,000 & 6.3 & 5.8 & 0 & 0 & 6.0 & 25.2 & 25.5 & 0 & 0 & 25.1 \\
\hline 3,500 & 0.2 & 6.5 & 0 & 6.2 & 6.3 & 27.1 & $3 \perp .5$ & 0 & 27.5 & 28.7 \\
\hline $\begin{array}{c}4,000 \\
\text { A thove } \\
\quad 1,000^{2}\end{array}$ & 4.5 & 0 & 0 & 2.0 & 3.2 & 23.6 & 0 & 0 & 15.1 & 19.4 \\
\hline
\end{tabular}

I Time after irendialion when pollen was used.

$2 \mathrm{Na}$ seed.

pendently by irradiation and the effects may be manifested separately. Usually, as staled by Brewbaker and Emery (D) and others for seed aboltion--many were observed from 1,500 $\mathrm{x}$ up in this experiment, and inviability-very low gemunation at higher doses are caused mostly by enıryo lethality ratled than endosperm damage. Seed abortion and endosperm underdevelopment were not systemntically scored in this experiment, even though incidental observation showed an incrense of such abnormal kernels associated with increasing doses.

As shown in table 1, the number of good kernels per ear was lower for high doses and longer time elapsing between treatment and use of the 
pollen, except for $R^{m b}$ pollen which shoved an increase at some doses. Within the limits and conditions of this experiment the pollen used 24 hours alter irradialion produced, on the average, more seeds per ear than the pollen used 48 hours after trealment. Doses above $2,000 \mathrm{r}$ increasingly reduced numbers of good kernels produced, although the amount of seed does nol bear a strong relation to the dose reseived below 1,500 r.

The results for germination abilily are not as consistent in thi- experiIIenl, as shown in table 2. It should be nofed that from 2,000 up $104,000 \mathrm{r}$ the quality of the seed itself was not at the same level as for lover doses, but the best were selected among those available at all levels. This partly accounts for bigher dose treatments having a marked decrease in the germination percentage. It is expected that daunge to the embryo will occur more of ten as the dose increases. This damage will be reflected in inability of the seeds to gelminale. In general, il can be stated that the decreasing germination percentage is a deflection of induced lethality to embryo by radiation. There does not seem to be any difference attributable to the stornge period after irmdiation of pollen.

Data on this kind of work are not so extensive for seedlings being produced by irratiated pollen, even though cylological observntions of raditition-lreated pollon have been made for Tradescantia, Dntura, and P'tunia (2). Schnidt and Frolik, (12) compared the effects of themal unutrous and $X$-rays on pollen and seeds of corn. They obtained a decicuse in seedling' height when seeds received about 7,500 $\mathrm{r}$ and pollen received about $1,200 \mathrm{r}$.

The average height of the scedlings did not show a slrong dose mouscon. If the scedling lived, it grew about as well, regardless of the dose recrived by the pollen grain giving rise to the seed. There might be some reduction of height at the highest doses, but the number of plants surviving to provide measurements was less than five for any group above $2,500 \mathrm{r}$, and many of the groups had no survivors, thus recording a zero for scedling height. All survivors at 7 days continued to grow to 14 days when they were all discarded. The rate of growth from 7 to 14 days showed no influence of the dose. Thus, if a plank survived the initial growth, il continued through the seedling slage. The radiation damage was manifest as luck of seed produced by the irradiated polles, or by lack of germination of seed thati were produced, but was not, a factor in scedling height.

\section{SUMMARY}

Corn lassels were irrulialed usiug Go 60 gamma rays at doso levels from 250 10 20,000 r. Twenty-four and forty-eight. hours after irradiation the pollen was collected from the tassels and used to fertilize ears. The quantity of good secds per car, the germination percentage of these good 
seeds, and the seedling height 7 and 14 days later of the plants from these gernimated seeds were recorded. No seeds were obtained beyond 4,000 r. There was litue effeet from pollen used 24 hours after treatment comparcd with pollen used 48 hours after treatment for any of the characters measured. There was a general dose response for number of good seeds per ear, and also in the percentage of germinution of those seeds classified as good. 'The higher doses reduced both numbers of good seeds and their germiuation. There was no evident dose response of seedling height. If the seed clid gominate it g'rew about as well as any at the dose levels measured.

\section{RESLMEN}

Se irradiaron inflorescencias de máz con rayos gamma de cobalto-60, exponiéndolats a una dosis que flucluó entre 250 y 20,000 roentgenios. Veinticuntro y 18 horas después de irradiadas, se recobró el polen pau'it. fertilizur las mazorcas. Se obtuvieron los siguientes datos: número de semillas buenas, o sea, semillas bien desurrolladas; porcentaje de gerninación cle la semilla buena, y altura de las plantas a los 7 y 14 días después de haber greminado la semilla. No se obturo semilla de lá que se irradió rou una dosis en 'xeeso de 1,000 roentgenios. El polen que se trató por 2t horas afretó poro los cararteres que se midieron, al compararso con el que se tralo por 18 horas. Tat rencción fue gencral en cuanto a la cantidad de buena semilla producida por matzor'al y a su porentaje de germiuación. Las dosis allas disminuyeron tanto la cantidid de semilla buena como el porecofaje de germinarión. No hubo eridencia en cuanto a la reneción de las plantas irendiadas cou referencia a su altura. Si la semilla germina, su crecinuiento es igual sin inuportar la dosis aplicada.

\section{I.ITERATURE CITED}

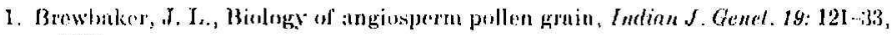
1957.

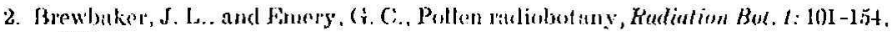
1968.

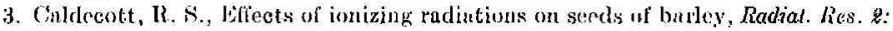
330-350, 1955.

4. Frolik, L. F., and Morris, R., Effets of irradiating muize pollen in a nucleur reactor on the $F_{1}$ plants, Science 3: 153-1, 1050.

5. - -., and-...- - Xenia efinets of irradiating corn pollen in a nuclear resctor, agron. f. 42: $2 ! 3-3-7,1050$.

6. Morris, R., Trunsmitferl pollen and eluromosmal aberraneies induecri in mazo:

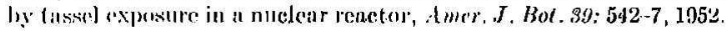

7. Meriele, L. W. and Meriole. R. P., Radionensitivity of the developing pland $\mathrm{em}$ bryo: Fumbumental aspects of rudiosensitivity, 14: Bronkhaven Natinual Lab)oralory 675, 1961.

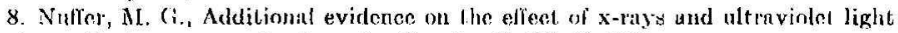
radintion on mutation in maze, Genetics 42: 273-82, 1957. 
9. Osborne, '1. S., and Bacon, J. A., Two inproved and inexpensive systems for noisture stabilization in seeds and other lissues, Plant Physiol. 86: 309-12, 1961.

10. Randolph, L. $\mathbb{F}$, Develnpriental morphology of the caryopsis in maize, $J$. $A \mathrm{gr}$. Res. 59: 881-916, 1936 .

11. Swansom, C, P., X-ruys and ultraviolet studies on pollen tubo chromosomes, $I_{\text {, }}$ The eflect of ultraviolet $(2537 \mathrm{~A})$ on $\mathrm{X}$-rity induced ehomosome aberrations, Geneties 29: 61-8, 1944.

12. Sehmidt, J. W., and Frolik, E. F., Compurntive effects of thermal neutrons irradiation of maize pollen and maizo soeds con subsequent seedling growth, $J$. Horch 19: 173-7, 1951.

13. Stadler, L. G., and Uber, F.M., Genetic efiects of ultra violet radiation in maize, Genetics 27: 84-118, 1942. 